\title{
VERIFICATION OF THE MAXIGASP AND POPGASP COMPUTER CODES FOR ENVIRONMENTAL DOSE ASSESSMENT
}

by

D. M. Hamby

Westinghouse Savannah River Company

Savannah River Site

Aiken, South Carolina 29808

DOE Contract No. DE-AC09-89SR18035

This paper was prepared in connection with work done under the above contract number with the U. S.

Department of Energy. By acceptance of this paper, the publisher and/or recipient acknowledges the U. S. Government's right to retain a nonexclusive, royalty-free license in and to any copyright covering this paper, along with the right to reproduce and to authorize others to reproduce all or part of the copyrighted paper. 


\section{DISCLAIMER}

This report was prepared as an account of work sponsored by an agency of the United States Government. Neither the United States Government nor any agency thereof, nor any of their employees, makes any warranty, express or implied, or assumes any legal liability or responsibility for the accuracy. completeness, or usefulness of any information, apparatus, product, or process disclosed, or represents that its use would not infringe privately owned rights. Reference herein to any specific commercial product. process, or service by trade name, trademark, manufacturer, or otherwise does not necessarily constitute or imply its endorsement, recommendation, or favoring by the United States Goverament or any agency thereof. The views and opinions of authors expressed herein do not necessarily state or reflect those of the United States -Government or any agency thereof.

This report has been reproduced directly from the best available copy.

Available to DOE and DOE contractors from the Office of Scientific and Technical Information. P. O. Box 62. Oak Ridge, TN 37831: prices available from (615) $576-8401$

Available to the public from the National Technical Information Service. U. S. Deparment of Commerce, 5285 Port Royal Rd., Springfield, VA 22161 


\section{DISCLAIMER}

Portions of this document may be illegible in electronic image products. Images are produced from the best available original document. 

ENVIRONMENTAL DOSE ASSESSMENT

David M. Hamby

January 19, 1995

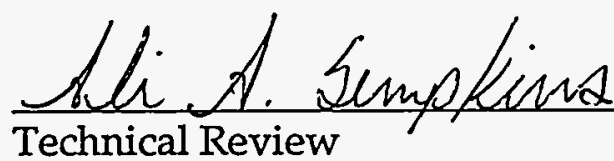

Westinghouse Savannah River Company

Savannah River Site

Aiken, SC 29808 


\title{
VERIFICATION OF THE MAXIGASP AND POPGASP COMPUTER CODES FOR ENVIRONMENTAL DOSE ASSESSMENT
}

\author{
by D.M. Hamby \\ Westinghouse Savannah River Company \\ Savannah River Site \\ Aiken, SC 29808
}

\section{SUMMARY}

MAXIGASP and POPGASP are environmental dosimetry codes that are based on the NRC dispersion module, $X O Q D O Q$, and the NRC dosimetry module, GASPAR. XOQDOQ and GASPAR have been verified previously. The four remaining modules of MAXIGASP and POPGASP control input/output functions and data transfer. The results of MAXIGASP and POPGASP have been verified by comparison of hand calculated doses with program output.

\section{INTRODUCTION}

Pursuant to software quality assurance requirements contained in DOE Orders $5700.6 \mathrm{C}$, "Quality Assurance," 1330.1C, "Computer Software," and 5400.1, "General Environmental Protection" and in WSRC Manual L1, Procedure 8.20, "Software Management and Quality Assurance," and as per instructions contained in WSRC-RP94-1159, "Software Quality Assurance Plan for Environmental Dosimetry" this report was prepared to complete the documentation for verification and validation of the MAXIGASP and POPGASP computer codes, which are used for environmental dose assessments.

The MAXIGASP and POPGASP codes are used to estimate offsite dose to the maximum individual and the 50-mile population, respectively. Each code consists of two primary and four secondary computer routines. The two primary modules of MAXIGASP and POPGASP have been verified separately. Atmospheric dispersion is calculated with XOQDOQ, a routine developed by the NRC based on the Regulatory Guide 1.111 (NRC77b) and verified on the SRS IBM mainframe (Ba91). The dosimetry routine, GASPAR, is based on the NRC Regulatory Guide 1.109 (NRC77a) and has been verified for SRS (Ha92a).

The purpose of this document is to verify the execution of MAXIGASP and POPGASP with regard to the secondary computer routines that handle data transfers. These modules control operations such as reading input and preparing data files, reading dispersion outputs from XOQDOQ, creating inputs for GASPAR, and printing results in a usable format. XOQDOQ and GASPAR are utilized in the same manner for both MAXIGASP and POPGASP with the exception that one code calculates dose to an 
individual while the other calculates dose to the population. Details on the functions of XOQDOQ and GASPAR can be found in the supporting documentation (Ec80; Sa82; Ba91; Ha91a; Ha92a).

This report is organized into two main sections. In the first section, brief descriptions of the four secondary modules are given along with their independent functions and their interactions with the other modules of the code. The second section goes through a hand verification of both MAXIGASP and POPGASP using an atmospheric tritium release as a benchmark case. Although not all subroutines within the two primary modules are accessed using this scenario, the detailed verifications on these primary routines are complete (Ba91; Ha92a) and this verification is designed only to demonstrate that the input/output functions are performed correctly between the primary and secondary modules.

\section{ORGANIZATION OF CODE MODULES}

MAXIGASP. The MAXIGASP program operates on the unclassified IBM mainframe using two primary and four secondary program modules. The two primary modules (XOQDOQ and GASPAR) have been described and verified separately (Ba91; Ha92a). The four secondary modules (MGPROTEM, MGPREXOQ, MGPREGAS, and MGDOSES) control input/output functions and data transfers between XOQDOQ and GASPAR. Operations of the secondary modules are described below.

The input template is read, printed, and written as a computer dataset by the MGPROTEM module: This routine is relatively short and non-complex. The resulting dataset is read by the MGPREXOQ module which prepares all input data necessary for the XOQDOQ program. MGPREXOQ reads the dataset created by MGPROTEM, the SRS boundary file, the local terrain file, and the meteorological data. The pertinent data from each of these files is written to a second dataset as input to XOQDOQ.

After the relative concentration factors are calculated by XOQDOQ, the MGPREGAS routine is invoked. MGPREGAS reads the XOQDOQ output and the original input and writes a dataset to be used as input for GASPAR. GASPAR calculates pathway- and organ-specific doses and writes the unformatted data to an output file. The last MAXIGASP module, MGDOSES, reads the datasets generated by MGPROTEM, $X O Q D O Q$, and GASPAR and writes the results to the printer in the requested format.

Typically, execution of MAXIGASP takes less than one minute (real-time) and utilizes five input datasets including the input template; boundary, topography, and meteorological data; and the external and internal DOE dose factors (DOE88a; DOE88b). These datasets have been verified separately (Ba91; Ha91b; Ha91c; Ha92a; Pa92).

POPGASP. The POPGASP program also operates on the unclassified IBM mainframe, again using two primary and four secondary program modules. The two primary modules (XOQDOQ and GASPAR) have been described and verified separately (Ba91; 
Ha92a) and are the same modules used in MAXIGASP. The four secondary modules (PGPROTEM, PGPREXOQ, PGPOP90, and PGPREGAS) control input/output functions and data transfers between XOQDOQ and GASPAR. Operations of the secondary modules are described below.

The input template is read, printed, and written as a computer dataset by the PGPROTEM module. This routine is very similar to the MGPROTEM routine. The resulting dataset is read by the PGPREXOQ module which prepares all input data necessary for the XOQDOQ program. PGPREXOQ reads the dataset created by PGPROTEM, the local terrain file, and the meteorological data. The pertinent data from each of these files is written to a second dataset as input to XOQDOQ.

After the relative concentration factors are calculated by XOQDOQ, the PGPOP 90 routine determines the 50-mile population distribution centered on the release point. The fourth secondary module, PGPREGAS, reads the input data from PGPROTEM, reads the population distribution from PGPOP90, and reads agricultural and sitespecific data from two data files. PGPREGAS compiles all of the data and writes an input file for the GASPAR program.

Typically, execution of POPGASP takes less than one minute (real-time) and utilizes seven input datasets including the input template; topography, meteorological, and population data; agricultural, humidity, and land usage factors; and the external and internal DOE dose factors (DOE88a; DOE88b). These datasets have been verified separately (Ba91; Ha91b; Ha91c; Ha92a; Ha93; Pa92).

\section{OPERATIONAL VERIFICATION}

The intent of the verification of MAXIGASP and POPGASP is to show that input and output data are transferred to and from each module appropriately. This verification will be carried out using an atmospheric tritium release scenario. Table 1 shows the input values used to execute MAXIGASP and POPGASP and the valid ranges for each input parameter. 
Table 1. Input parameter values for the benchmark case and valid ranges of inputs for code execution.

\begin{tabular}{|c|c|c|c|}
\hline Parameter & $\begin{array}{c}\text { MAXIGASP } \\
\text { Value }\end{array}$ & $\begin{array}{l}\text { POPGASP } \\
\text { Value }\end{array}$ & $\begin{array}{l}\text { Valid } \\
\text { Range }\end{array}$ \\
\hline Released Nuclides & 1 & * & $1-100$ \\
\hline Release Points & 1 & * & $1-5$ \\
\hline Operating Period (yr) & 40 & $201^{+}$ & $1-201$ \\
\hline Consumption & MAX & $*$ & AVG; MAX \\
\hline Milk Ingestion & COW & * & COW; GOAT \\
\hline Grade Elevation (ft) & \multicolumn{2}{|c|}{0} & $0-1000$ \\
\hline SRS East Coordinate & \multicolumn{2}{|c|}{58000} & any onsite value \\
\hline SRS North Coordinate & \multicolumn{2}{|c|}{62000} & any onsite value \\
\hline Met Tower Database & \multicolumn{2}{|c|}{$\mathrm{H}$} & $\mathrm{A}, \mathrm{C}, \mathrm{D}, \mathrm{F}, \mathrm{H}, \mathrm{K}, \mathrm{L}, \mathrm{P}$ \\
\hline Vent Air Velocity $(\mathrm{m} / \mathrm{s})$ & \multicolumn{2}{|c|}{0} & $0-1000$ \\
\hline Vent Diameter (m) & \multicolumn{2}{|c|}{0} & $0-50$ \\
\hline Release Height (m) & \multicolumn{2}{|c|}{62} & $0-100$ \\
\hline Building Height $(\mathrm{m})$ & \multicolumn{2}{|c|}{0} & $0-100$ \\
\hline Cross-Section (m) & \multicolumn{2}{|c|}{0} & $0-2000$ \\
\hline Wind Height $(\mathrm{m})$ & \multicolumn{2}{|c|}{62} & $0-100$ \\
\hline Heat Emission (cal/s) & \multicolumn{2}{|c|}{0} & $0-500$ \\
\hline Elemental Iodine & \multicolumn{2}{|c|}{1} & $0-1$ \\
\hline Release Amount (Ci) & \multicolumn{2}{|c|}{$10^{5}$} & $0-10^{6}$ \\
\hline
\end{tabular}

*parameter not used in POPGASP; ${ }^{+}$value of 201 indicates that Environmental Dose Commitment is to be calculated.

MAXIGASP Results. The MAXIGASP code has been verified for proper data transfer during execution. Output generated by MAXIGASP was carefully examined to confirm the appropriate transfer of data from one module to the next. Verification will proceed in a step-by-step fashion for each of the six modules.

The input template is read and printed by MGPROTEM. Examination of the MAXIGASP output shows that the printed template is consistent with the input template. Furthermore, based on parameter specifications printed as part of the XOQDOQ or GASPAR output, each input parameter value has been found to be written to the temporary dataset correctly. Output of the boundary and topographic files was confirmed with the SRS sitewide facilities map. These files are processed by MGPREXOQ. Meteorological data for the tower specified in the input template were inspected and no discrepancies were found. 
The XOQDOQ module reads the temporary datasets created by MGPROTEM and MGPREXOQ. Relative concentrations and relative deposition rates are calculated and printed as functions of distance and direction from the specified release point. The XOQDOQ module has been verified as a stand-alone computer code (Ba91).

Data from XOQDOQ is read into MGPREGAS which then prepares input for GASPAR. This module was verified based on examination of the MAXIGASP printout wherein relative concentrations from $X O Q D O Q$ were compared with the relative concentrations used in the GASPAR dose calculations. The comparison showed that the four concentration values needed in GASPAR were consistent with the concentration tables calculated by XOQDOQ. Three relative concentration values and one relative deposition rate are passed through MGPREGAS from XOQDOQ to GASPAR.

The GASPAR module uses the XOQDOQ input to estimate individual dose at the highest receptor location on the SRS boundary. This module also has been verified as a stand-alone computer code (Ha92a). The final module of MAXIGASP is MGDOSES where the output from GASPAR is formatted and the results printed.

Hand calculations using the MAXINE spreadsheet (Ha94) are presented in Appendix A. The pathway-specific dose estimates calculated with MAXINE are identical (within rounding) to those generated by MAXIGASP. The MAXIGASP code resulted in inhalation, vegetable ingestion, meat ingestion, and milk ingestion maximum individual doses of $0.0351,0.0244,0.00413$, and $0.00977 \mathrm{mrem}$, respectively. As seen in the Appendix, MAXINE's pathway specific results are 0.035, 0.024, 0.0041, and 0.0097 mrem, respectively. The MAXIGASP printout is maintained in the Environmental Dosimetry document management system.

POPGASP Results. Most of the data transfers occurring between modules of the POPGASP code are similar to those in MAXIGASP and have been verified in the same manner. The PGPOP90 module generates a population distribution, centered on the release point, based on data from the 1990 census. This database was developed by the University of South Carolina for SRS. The total population within 50-miles of the Savannah River reservation is approximately 620,000 . Each of these persons is assumed to be an adult since a complete library of age-specific dose factors is not available. Since the data are shown to be transferring correctly, verification efforts are focused on the calculation of population dose. Again, as with the verification of MAXIGASP, an atmospheric release of $100,000 \mathrm{Ci}$ HTO from the center of the SRS is assumed as the release scenario. The dose calculations are not being tested so much as the handling of data.

Population dose is calculated utilizing site-specific agricultural and demographic data. The necessary information includes the 50-mile population distribution and the meat, milk, and vegetation production distributions (see Appendix B, Tables 1-4). These distributions are in the form of arrays of 16 compass sectors $\times 5$ receptor distances, creating 80 area segments in which population dose is calculated. Average individual dose (Appendix B, Table 5), as a function of receptor distance and direction from the 
release point, is calculated in GASPAR and also has been calculated and verified by hand for this exercise. Table 6 of Appendix B contains the 50-mile population dose, D, for each area segment and is calculated using the formula:

$$
D=\left(P_{t} D_{i}\right)+\left(P_{v} D_{v}\right)+\left(P_{m} D_{m}\right)+\left(P_{b} D_{b}\right)
$$

where $D_{i}, D_{v}, D_{m}$, and $D_{b}$ are pathway-specific doses via inhalation, vegetation, milk, and meat consumption, respectively, and where $P_{t}, P_{v}, P_{m}$, and $P_{b}$ are the total population in a given area segment and the effective populations involved in the consumption of vegetation, milk, and meat, respectively.

The effective populations are determined for each area segment based on the production yields and the average consumption rate of each commodity. For example, the consumption rate of milk is assumed to be $230 \mathrm{~L} / \mathrm{yr}$ per person ( $\mathrm{Ha92b}$ ) and the milk production yield for a given area segment is $480,000 \mathrm{~L} / \mathrm{yr}$. Therefore, the milkconsumption effective population, $\mathrm{P}_{\mathrm{m}}$, for that area segment is:

$$
\mathrm{P}_{\mathrm{m}}=(480,000 \mathrm{~L} / \mathrm{yr} / 230 \mathrm{~L} / \mathrm{yr} / \text { person })=2087
$$

indicating the number of persons that the amount of milk produced in that segment will support. Since it is assumed that a commodity consumed in a given segment was also produced in that segment, the number of persons assumed for the pathway-specific dose calculation will be the lesser of the true population or the effective population.

The average dose distribution (Table 5, Appendix B) was obtained by hand calculation of the tritium dose using the segment-specific relative concentration calculated by $X O Q D O Q$. Doses calculated for each area segment in the population dose distribution (Table 6, Appendix B) are determined using Equation 1. The total population dose of 5.2 person-rem was determined by integrating the population dose distribution over all 80 segments. The comparison run of POPGASP resulted in a total population dose of 5.22 person-rem. . The POPGASP output is maintained in the Environmental Dosimetry document management system. 


\section{REFERENCES}

Ba91 Bauer, L.R. Modelling chronic atmospheric releases at the SRS: evaluation and verification of XOQDOQ. Westinghouse Savannah River Company. Aiken, SC: Report No. WSRC-RP-92-320; 1991.

Ec80 Eckerman, K.F.; Congel, F.J.; Roecklein, A.K.; Pasciak, W.J. User's guide to GASPAR code. U.S. Nuclear Regulatory Commission. Washington, DC: Report No. NUREG/-0597; 1980.

Ha91a Hamby, D.M. Environmental dose assessment manual. Westinghouse Savannah River Company. Aiken, SC: Report No. WSRC-IM-91-1; 1991.

Ha91b Hamby, D.M. Verification of the GASPAR ICRP-30 Dose Factor Library, SRL-ETS-910583, Westinghouse Savannah River Company, Aiken, SC: December 9, 1991.

Ha91c Hamby, D.M. Verification of the GASPAR ICRP-30 Noble Gas Dose Factor Library and SRS Site-Specific Data, SRL-ETS-910585, Westinghouse Savannah River Company, Aiken, SC: December 10, 1991.

Ha92a Hamby, D.M. Verification of the GASPAR dose assessment module used in MAXIGASP and POPGASP. Westinghouse Savannah River Company. Aiken, SC: Report No. WSRC-RP-92-418; 1992.

Ha92b Hamby, D.M. Site-specific parameter values for the Nuclear Regulatory Commission's food pathway dose model. Health Physics. 62:136-143; 1992.

Ha93 Hamby, D.M. Development of Onsite and Offsite Population Distributions for Use in Dose Assessment Codes, SRT-ETS-930635. Westinghouse Savannah River Company, Aiken, SC: June 18, 1993.

Ha94 Hamby, D.M. MAXINE: An improved metholodgy for estimating maximum individual dose from chronic atmospheric radioactive releases. Westinghouse Savannah River Company. Aiken, SC: Report No. WSRC-TR94-053; 1994.

Pa92 Parker, M.J.; Addis, R.P.; Hunter, C.H.; Kurzeja, R.J.; Tatum, C.P.; Weber, A.H. The 1987-1991 Savannah River Site Meteorological Data Base (U). WSRC-RP-92-598. Westinghouse Savannah River Company. Aiken, SC: May 19, 1992.

Sa82 Sagendorf, J.F.; Goll, J.T.; Sandusky, W.F. XOQDOQ: Computer program for the meteorological evaluation of routine effluent releases at nuclear power 
stations. U.S. Nuclear Regulatory Commission. Washington, DC: Report No. NUREG/CR-2919; 1982.

DOE88a U.S. DOE. External dose-rate conversion factors for calculation of dose to the public. U.S. Department of Energy. Washington, DC: Report No. $\mathrm{DOE} / \mathrm{EH}-0070 ; 1988$.

DOE88b U.S. DOE. Internal dose conversion factors for calculation of dose to me public. U.S. Department of Energy. Washington, DC: Report No. DOE/EH0071; 1988.

NRC77a U.S. NRC. Calculation of annual doses to man from routine releases of reactor effluents for the purpose of evaluating compliance with 10 CFR Part 50, Appendix I. U.S. Nuclear Regulatory Commission. Washington, DC: Regulatory Guide 1.109; 1977.

NRC77b U.S. NRC. Methods for estimating atmospheric transport and dispersion of gaseous effluents in routine releases from light-water-cooled reactors. U.S. Nuclear Regulatory Commission. Washington, DC: Regulatory Guide 1.111, Rev. 1; 1977. 


\section{APPENDIX A}

\section{MAXINE Output}




\section{Bench Mark Run for MAXIGASP Comparison (Verification of MAXIGASP \& POPGASP Report)}

\begin{tabular}{rccc}
\multicolumn{5}{c}{ EXPOSURE PARAMETERS } \\
Relative Concentration (X/Q): & $1.5 \mathrm{E}-08$ & $(\mathrm{sec} / \mathrm{m} 3)$ & \\
Decayed X/Q: & $1.4 \mathrm{E}-08$ & $(\mathrm{sec} / \mathrm{m} 3)$ & \\
Depleted X/Q: & $1.3 \mathrm{E}-08$ & $(\mathrm{sec} / \mathrm{m} 3)$ & \\
Relative Deposition (D/Q): & $6.0 \mathrm{E}-11$ & $(1 / \mathrm{m} 2)$ & \\
Distance to Receptor: & 15479 & $(\mathrm{~m})$ & \\
Consumption (AVG, MAX, value): & Max & 276 & $(\mathrm{~kg} / \mathrm{yr})$ \\
Consumption (AVG, MAX, value): & Max & 43 & $(\mathrm{~kg} / \mathrm{yr})$ \\
Consumption (AVG, MAX, value): & Max & 230 & $(\mathrm{~L} / \mathrm{yr})$ \\
Consumption (AVG, MAX, value): & Max & 81 & $(\mathrm{~kg} / \mathrm{yr})$
\end{tabular}

Origin of Milk (Cow or Goat): Cow

Deposition Buildup Time: 40

Breathing Rate: $8,000 \quad(\mathrm{~m} 3 / \mathrm{yr})$

Elemental lodine Fraction:

1.00

Absolute Humidity:

Tritium Plant-to-Air Ratio:

$0.01140 \quad(\mathrm{~kg} / \mathrm{m} 3)$

Shielding Factor:

0.50

0.70

Fraction of Year C-14 Released:

1.00

Retained Fraction (iodines):

1.00

Retained Fraction (particulates):

0.20

Weathering Rate Constant:

18.1

Crop Exposure Time:

0.192

$(1 / y r)$

Pasture Grass Exposure Time:

0.0822

(yr)

Pasture Grass Productivity:

Produce Productivity:

1.8

(yr)

0.7

$(\mathrm{kg} / \mathrm{m} 2)$

Surface Soil Density $(15 \mathrm{~cm})$ :

240

$(\mathrm{kg} / \mathrm{m} 2)$

Pasture Grass Holdup Time:

Stored Feed Holdup Time:

Leafy Vegetable Holdup Time:

Produce Holdup Time:

0.00000

$(\mathrm{kg} / \mathrm{m} 2)$

$0.24700 \quad$ (yrs)

$0.00274 \quad$ (yrs)

$0.16400 \quad$ (yrs)

Milk Cattle Feed Consumption (52):

44

(kg/day)

Beef Cattle Feed Consumption:

44

Feed-Milk-Man Transport Time:

Fraction of Year on Pasture (beef):

0.00822

(kg/day)

$(y r)$

Fraction of Year on Pasture (milk):

Fraction Intake from Pasture (beef):

1.00

1.00

1.00 suggested

0.75

Fraction Intake from Pasture (milk):

Slaughter to Consumption Time:

Fraction of Produce from Garden:

0.56

0.56 suggested

0.0164

(yr)

Fraction of Leafy Vegs from Garden: $\quad 1.00$ 


\section{SOURCE TERM ENTRY}

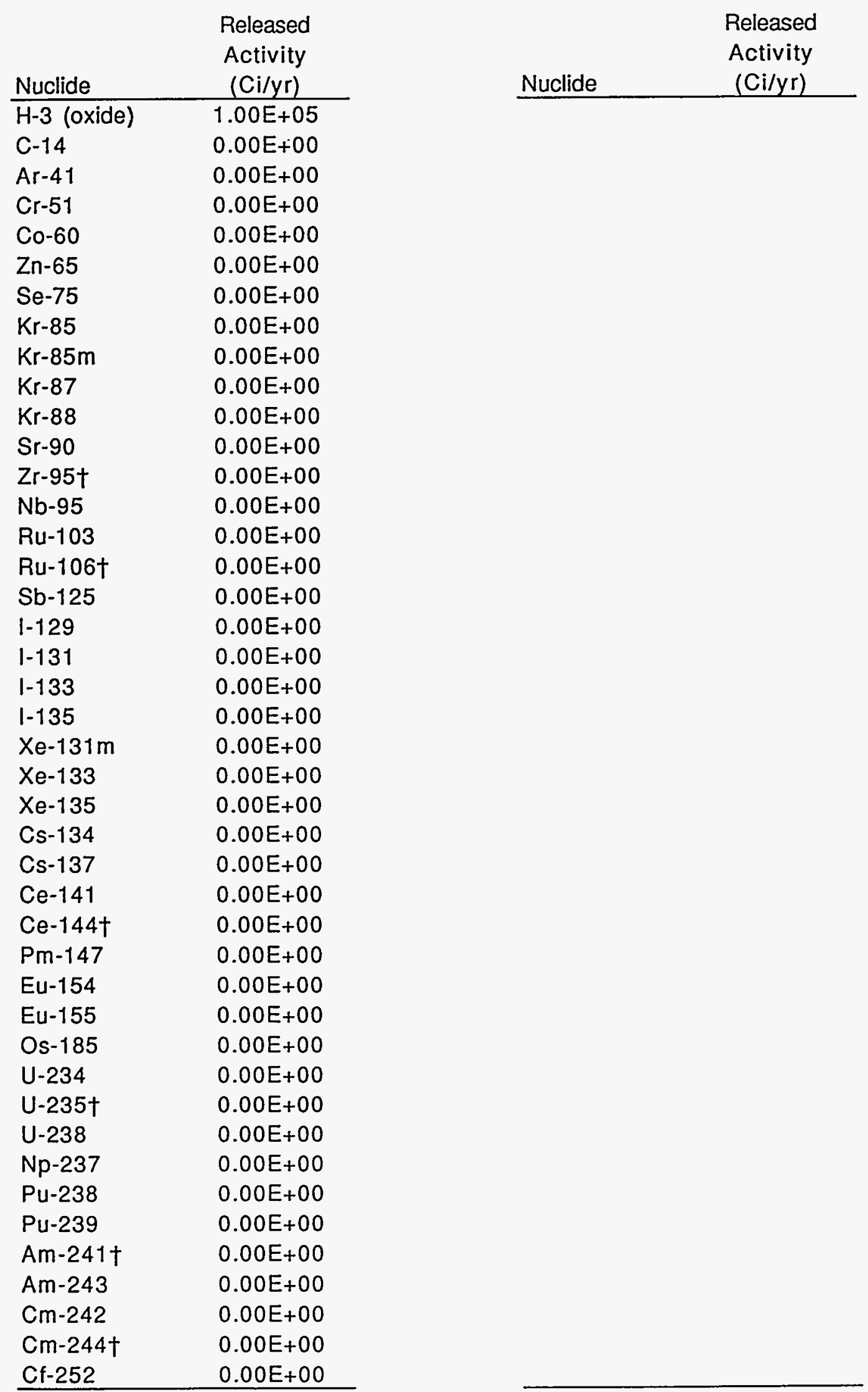

†Denotes preferred isotope when isotopic breakdown in not available. 


\section{Atmospheric Transport and External Dose Factors}

\begin{tabular}{|c|c|c|c|c|c|c|}
\hline Nuclide & $\begin{array}{c}\text { Deposition } \\
\text { Rate } \\
\text { (uCi/m2 yr) }\end{array}$ & $\begin{array}{c}\text { Atmospheric } \\
\text { Concentration } \\
(\mathrm{uCi} / \mathrm{m} 3)\end{array}$ & $\begin{array}{c}\text { Plume-Shine } \\
\text { EDEDFs } \\
\frac{(\mathrm{mrem} \mathrm{m} 3)}{(\mathrm{yr} u \mathrm{Ci})}\end{array}$ & $\begin{array}{l}\text { Plume-Shine } \\
\text { Skin DFs } \\
\text { (mrem m3) } \\
\text { (yr uCi) }\end{array}$ & $\begin{array}{l}\text { Ground-Shine } \\
\text { EDEDFs } \\
\frac{\text { (mrem m2) }}{(y r u C i)}\end{array}$ & $\begin{array}{l}\text { Ground-Shine } \\
\text { Skin DFs } \\
\frac{(\text { mrem m2) }}{(y r u C i)}\end{array}$ \\
\hline $\mathrm{H}-3$ & $\%$ & $4.6 E-05$ & & & & \\
\hline$C-14$ & & $0.0 E+00$ & & & & \\
\hline Ar -41 & \% & $0.0 E+00$ & $6.63 E+03$ & $1.22 E+04$ & & 原. \\
\hline $\mathrm{Cr}-51$ & $0.0 E+00$ & $0.0 E+00$ & & & $3.41 E+00$ & $4.53 E+00$ \\
\hline Co-60 & $0.0 E+00$ & $0.0 E+00$ & & & $2.27 E+02$ & $3.10 E+02$ \\
\hline $\mathrm{Zn}-65$ & $0.0 E+00$ & $0.0 E+00$ & & & $5.48 E+01$ & $7.45 E+01$ \\
\hline Se-75 & $0.0 E+00$ & $0.0 E+00$ & & & $4.32 E+01$ & $5.65 E+01$ \\
\hline$K r-85$ & ४ 114 १ै। & $0.0 E+00$ & $1.12 \mathrm{E}+01$ & $1.58 E+03$ & & $13 \%$ \\
\hline $\mathrm{Kr}-85 \mathrm{~m}$ & & $0.0 E+00$ & $8.17 E+02$ & $2.62 E+03$ & & \\
\hline $\mathrm{Kr}-87$ & & $0.0 E+00$ & $4.47 E+03$ & $1.65 E+04$ & & \\
\hline $\mathrm{Kr}-88^{\star}$ & 14 & $0.0 E+00$ & $1.49 E+04$ & $3.92 E+04$ & & $\$, 4 . \%$ \\
\hline Sr $-90^{*}$ & $0.0 E+00$ & $0.0 E+00$ & & & $0.00 E+00$ & $1.27 E+03$ \\
\hline $\mathrm{Zr}-95^{\star}$ & $0.0 E+00$ & $0.0 E+00$ & & & $1.52 E+02$ & $2.10 E+02$ \\
\hline $\mathrm{Nb}-95$ & $0.0 E+00$ & $0.0 E+00$ & & & $7.76 E+01$ & $1.10 E+02$ \\
\hline $\mathrm{Ru}-103^{\star}$ & $0.0 E+00$ & $0.0 E+00$ & & & $5.01 E+01$ & $7.19 E+01$ \\
\hline$R u-106^{*}$ & $0.0 E+00$ & $0.0 \mathrm{E}+00$ & & & $2.10 E+01$ & $1.66 E+03$ \\
\hline$S b-125$ & $0.0 E+00$ & $0.0 E+00$ & & & $4.43 E+01$ & $6.71 E+01$ \\
\hline $\mid-129$ & $0.0 E+00$ & $0.0 E+00$ & & & $2.20 E+00$ & $5.30 E+00$ \\
\hline $\mid-131^{\circ}$ & $0.0 E+00$ & $0.0 E+00$ & & & $4.04 E+01$ & $7.56 E+01$ \\
\hline $1-133^{*}$ & $0.0 E+00$ & $0.0 E+00$ & & & $6.67 E+01$ & $5.39 E+02$ \\
\hline $1-135$ & $0.0 E+00$ & $0.0 E+00$ & & & $1.45 E+02$ & $5.62 E+02$ \\
\hline $\mathrm{Xe-131m}$ & $4 \% 1 \%$ & $0.0 E+00$ & $4.29 E+01$ & $E+02$ & & \\
\hline $\mathrm{Xe}-133$ & ৷ & $0.0 E+00$ & $1.76 E+02$ & $5.81 E+02$ & & \\
\hline $\mathrm{Xe}-135$ & \% & $0.0 E+00$ & $1.25 E+03$ & $3.64 E+03$ & & 1., \\
\hline Cs-134 & $0.0 E+00$ & $0.0 E+00$ & & & $1.58 E+02$ & $2.50 E+02$ \\
\hline Cs-137* & $0.0 E+00$ & $0.0 E+00$ & & & $5.78 E+01$ & $2.09 E+02$ \\
\hline $\mathrm{Ce}-141$ & $0.0 E+00$ & $0.0 E+00$ & & & $8.78 E+00$ & $1.60 E+01$ \\
\hline $\mathrm{Ce}-144^{\star}$ & $0.0 E+00$ & $0.0 E+00$ & & & $5.10 E+00$ & $1.47 E+03$ \\
\hline $\mathrm{Pm}-147$ & $0.0 E+00$ & $0.0 E+00$ & & & $4.10 E-04$ & $4.96 \mathrm{E}-04$ \\
\hline Eu-154 & $0.0 E+00$ & $0.0 E+00$ & & & $1.21 E+02$ & $3.12 E+02$ \\
\hline Eu-155 & $0.0 E+00$ & $0.0 E+00$ & & & $7.15 E+00$ & $9.39 E+00$ \\
\hline Os-185 & $0.0 E+00$ & $0.0 E+00$ & & & $7.29 E+01$ & $1.07 E+02$ \\
\hline U-234 & $0.0 \mathrm{E}+00$ & $0.0 E+00$ & & & 8.07E-02 & $6.40 \mathrm{E}-01$ \\
\hline$U-235$ & $0.0 E+00$ & $0.0 E+00$ & & & $1.71 E+01$ & $2.30 E+01$ \\
\hline$U-238$ & $0.0 E+00$ & $0.0 E+00$ & & & $6.46 \mathrm{E}-02$ & $5.30 \mathrm{E}-01$ \\
\hline $\mathrm{Np}-237$ & $0.0 E+00$ & $0.0 E+00$ & & & $3.24 E+00$ & $7.50 E+00$ \\
\hline $\mathrm{Pu}-238$ & $0.0 E+00$ & $0.0 E+00$ & & & $8.58 E-02$ & $7.20 E-01$ \\
\hline Pu-239 & $0.0 E+00$ & $0.0 E+00$ & & & $3.78 E-02$ & $2.80 E-01$ \\
\hline$A m-241$ & $0.0 E+00$ & $0.0 E+00$ & & & $2.99 E+00$ & $6.40 E+00$ \\
\hline Am-243 & $0.0 E+00$ & $0.0 E+00$ & ০ & & $6.61 E+00$ & $1.06 E+01$ \\
\hline $\mathrm{Cm}-242^{*}$ & $0.0 E+00$ & $0.0 E+00$ & & & $1.79 E-01$ & $1.45 E+00$ \\
\hline $\mathrm{Cm}-244$ & $0.0 E+00$ & $0.0 E+00$ & & 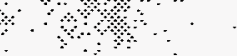 & $8.29 E-02$ & $6.60 E-01$ \\
\hline Cf-252 & $0.0 E+00$ & $0.0 E+00$ & & 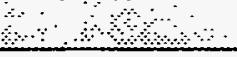 & $6.34 \mathrm{E}-02$ & 4.70E-01 \\
\hline
\end{tabular}

Nuclides in BOLD have modified deposition and atm. concentration models.

-These dose factors include contributions from daughter radiations (as per SRL-ETS-910233). 
CONVERSION FACTORS

\begin{tabular}{|c|c|c|c|c|c|c|}
\hline Nuclide & $\begin{array}{c}\text { Decay } \\
\text { Constant } \\
(1 / y r) \\
\end{array}$ & $\begin{array}{c}\text { Inhalation EDE } \\
\text { Dose Factor } \\
\text { (rem/uCi) }\end{array}$ & $\begin{array}{c}\text { Ingestion EDE } \\
\text { Dose Factor } \\
\text { (rem/uCi) }\end{array}$ & $\begin{array}{c}\text { Vegetable } \\
\text { to Soil } \\
\text { Ratio } \\
\end{array}$ & $\begin{array}{c}\text { Cow Milk } \\
\text { Transfer } \\
(d / L)\end{array}$ & $\begin{array}{c}\text { Intake To Meat } \\
\text { Transfer } \\
(\mathrm{d} / \mathrm{kg})\end{array}$ \\
\hline $\mathrm{H}-3$ & $5.61 E-02$ & $9.5 E-05$ & $6.3 E-05$ & $4.8 E+00$ & $1.0 E-02$ & $1.2 \mathrm{E}-02$ \\
\hline C-14 & $1.21 E-04$ & $2.4 E-05$ & $2.1 E-03$ & $5.5 E+00$ & $1.2 E-02$ & $3.1 E-02$ \\
\hline Ar-41 & $3.31 E+03$ & & & & ঐ. & (1) \\
\hline Cr-51 & $9.13 E+00$ & 2.6E-04 & $1.3 E-04$ & 2.5E-04 & 2.2E-03 & $2.4 E-03$ \\
\hline Co-60 & 1.32E-01 & $1.5 E-01$ & 2.6E-02 & $9.4 E-03$ & 1.0E-03 & 1.3E-02 \\
\hline $\mathrm{Zn}-65$ & $1.03 E+00$ & $1.8 E-02$ & $1.4 E-02$ & $4.0 E-01$ & $3.9 E-02$ & $3.0 E-02$ \\
\hline Se-75 & $2.11 E+00$ & $8.2 E-03$ & $8.8 E-03$ & $1.3 E+00$ & $4.5 E-02$ & $1.5 E-02$ \\
\hline$K r-85$ & $6.46 \mathrm{E}-02$ & & & & & \\
\hline $\mathrm{Kr}-85 \mathrm{~m}$ & $1.36 E+03$ & & & & & \\
\hline $\mathrm{Kr}-87$ & $4.76 E+03$ & & & & & \\
\hline $\mathrm{Kr}-88$ & $2.14 E+03$ & \%. & ?े & 4 & 4 & \\
\hline Sr-90 & 2.38E-02 & $1.3 E+00$ & $1.3 E-01$ & $1.7 E-02$ & 8.0E-04 & $6.0 E-04$ \\
\hline $\mathrm{Zr}-95$ & $3.85 E+00$ & $1.9 E-02$ & $3.4 E-03$ & $1.7 E-04$ & $5.0 E-06$ & $3.4 \mathrm{E}-02$ \\
\hline $\mathrm{Nb}-95$ & $7.22 E+00$ & $4.5 E-03$ & $2.2 E-03$ & $9.4 E-03$ & $2.5 E-03$ & $2.8 E-01$ \\
\hline$R u-103$ & $6.37 E+00$ & $7.8 E-03$ & 2.7E-03 & $5.0 E-02$ & $1.0 E-06$ & 4.0E-01 \\
\hline$R u-106$ & $6.84 E-01$ & 4.4E-01 & $2.1 E-02$ & $5.0 E-02$ & $1.0 E-06$ & 4.0E-01 \\
\hline$S b-125$ & $2.50 E-01$ & $9.8 E-03$ & 2.6E-03 & & & \\
\hline $1-129$ & $4.35 E-08$ & $1.8 E-01$ & $2.8 E-01$ & $2.0 E-02$ & $6.0 E-03$ & $2.9 E-03$ \\
\hline $\mid-131$ & $3.14 E+01$ & $3.2 E-02$ & $5.3 E-02$ & $2.0 E-02$ & $6.0 E-03$ & $2.9 E-03$ \\
\hline $1-133$ & $2.92 E+02$ & $5.4 E-03$ & $1.0 \mathrm{E}-02$ & 2.0E-02 & $6.0 E-03$ & $2.9 \mathrm{E}-03$ \\
\hline $1-135$ & $9.21 E+02$ & $1.1 E-03$ & $2.0 E-03$ & $2.0 E-02$ & $6.0 E-03$ & $2.9 E-03$ \\
\hline $\mathrm{xe}-131 \mathrm{~m}$ & $2.14 E+01$ & & & & & ও \\
\hline $\mathrm{Xe}-133$ & $4.82 E+01$ & & & & & \\
\hline $\mathrm{Xe}-135$ & $6.68 E+02$ & & & & & ৷.। \\
\hline Cs-134 & $3.37 E-01$ & 4.7E-02 & $7.4 E-02$ & $1.0 E-02$ & 1.2E-02 & $4.0 \mathrm{E}-03$ \\
\hline Cs-137 & $2.25 E-02$ & $3.2 E-02$ & $5.0 E-02$ & $1.0 E-02$ & 1.2E-02 & $4.0 E-03$ \\
\hline Ce-141 & $7.79 E+00$ & $8.5 E-03$ & 2.6E-03 & $2.5 E-03$ & $6.0 \mathrm{E}-04$ & $1.2 E-03$ \\
\hline $\mathrm{Ce}-144$ & 8.92E-01 & $3.5 E-01$ & $2.0 \mathrm{E}-02$ & $2.5 E-03$ & $6.0 \mathrm{E}-04$ & $1.2 E-03$ \\
\hline$P m-147$ & $2.64 \mathrm{E}-01$ & $3.4 E-02$ & $9.5 E-04$ & & & \\
\hline Eu-154 & $7.88 E-02$ & 2.6E-01 & $9.1 E-03$ & & & \\
\hline Eu-155 & $1.40 E-01$ & $3.9 E-02$ & $1.3 E-03$ & & & \\
\hline Os-185 & $2.70 E+00$ & $1.0 E-02$ & $2.1 E-03$ & 5.0E-02 & $5.0 \mathrm{E}-03$ & 4.0E-01 \\
\hline$U-234$ & $2.84 E-06$ & $1.3 E+02$ & 2.6E-01 & $2.5 E-03$ & 5.0 E-04 & $3.4 E-04$ \\
\hline U-235 & $9.81 E-10$ & $1.2 E+02$ & $2.5 E-01$ & 2.5E-03 & $5.0 E-04$ & $3.4 E-04$ \\
\hline$U-238$ & $1.55 E-10$ & $1.2 E+02$ & 2.3E-01 & $2.5 E-03$ & $5.0 E-04$ & $3.4 E-04$ \\
\hline$N p-237$ & $3.25 E-07$ & $4.9 E+02$ & $3.9 E+00$ & $2.5 E-03$ & $5.0 E-06$ & $2.0 E-04$ \\
\hline$P u-238$ & $7.88 E-03$ & $4.6 E+02$ & $3.8 E+00$ & $2.5 E-04$ & $2.0 E-06$ & $1.4 E-05$ \\
\hline Pu-239 & $2.84 \mathrm{E}-05$ & $5.1 E+02$ & $4.3 E+00$ & $2.5 E-04$ & $2.0 E-06$ & $1.4 E-05$ \\
\hline Am-241 & $1.60 E-03$ & $5.2 E+02$ & $4.5 E+00$ & $2.5 E-04$ & 5.0E-06 & $2.0 E-04$ \\
\hline Am-243 & 9.39E-05 & $5.2 E+02$ & $4.5 E+00$ & $2.5 E-04$ & 5.0E-06 & $2.0 E-04$ \\
\hline $\mathrm{Cm}-242$ & $1.55 E+00$ & $1.7 E+01$ & $1.1 \mathrm{E}-01$ & $2.5 E-03$ & 5.0E-06 & $2.0 E-04$ \\
\hline $\mathrm{Cm}-244$ & $3.88 E-02$ & $2.7 E+02$ & $2.3 E+00$ & $2.5 E-03$ & 5.0E-06 & $2.0 E-04$ \\
\hline Cf-252 & $2.62 E-01$ & $1.3 E+02$ & $9.4 \mathrm{E}-01$ & $2.5 E-03$ & $5.0 \mathrm{E}-06$ & $2.0 E-04$ \\
\hline
\end{tabular}


FOOD AND FODDER CONCENTRATIONS

\begin{tabular}{|c|c|c|c|c|c|c|}
\hline Nuclide & $\begin{array}{c}\text { Other } \\
\text { Vegetables } \\
\text { (uCi/kg) }\end{array}$ & $\begin{array}{c}\text { Leafy } \\
\text { Vegetables } \\
\text { (uCi/kg) }\end{array}$ & $\begin{array}{c}\text { Milk } \\
(\mathrm{uCi} / \mathrm{L})\end{array}$ & $\begin{array}{c}\text { Meat } \\
(\mathrm{uCi} / \mathrm{kg})\end{array}$ & $\begin{array}{c}\text { Pasture } \\
\text { Grass } \\
\text { (uCi/kg) }\end{array}$ & $\begin{array}{c}\text { Stored } \\
\text { Feed } \\
(\mathrm{uCi} / \mathrm{kg})\end{array}$ \\
\hline $\mathrm{H}-3^{\circ}$ & $1.5 \mathrm{E}-03$ & $1.5 E-03$ & $6.7 E-04$ & 8.0E-04 & $1.5 E-03$ & $1.5 \mathrm{E}-03$ \\
\hline $\mathrm{C}-14^{\circ}$ & $0.0 E+00$ & $0.0 E+00$ & $0.0 E+00$ & $0.0 E+00$ & $0.0 E+00$ & $0.0 E+00$ \\
\hline Ar -41 & \% & ঝ. & & & & ২. \\
\hline $\mathrm{Cr}-51$ & $0.0 E+00$ & $0.0 E+00$ & $0.0 E+00$ & $0.0 E+00$ & $0.0 E+00$ & $0.0 \mathrm{E}+00$ \\
\hline Co-60 & $0.0 E+00$ & $0.0 E+00$ & $0.0 E+00$ & $0.0 E+00$ & $0.0 E+00$ & $0.0 E+00$ \\
\hline $\mathrm{Zn}-65$ & $0.0 E+00$ & $0.0 E+00$ & $0.0 E+00$ & $0.0 E+00$ & $0.0 E+00$ & $0.0 \mathrm{E}+00$ \\
\hline Se-75 & $0.0 E+00$ & $0.0 E+00$ & $0.0 E+00$ & $0.0 E+00$ & $0.0 E+00$ & $0.0 E+00$ \\
\hline $\mathrm{Kr}-85$ & & & & & & \\
\hline $\mathrm{Kr}-85 \mathrm{~m}$ & & & & & & \\
\hline $\mathrm{Kr}-87$ & & & 14. & 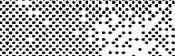 & 4 & (1. \\
\hline $\mathrm{Kr}-88$ & & & & & & \\
\hline Sr-90 & $0.0 E+00$ & $0.0 E+00$ & $0.0 E+00$ & $0.0 E+00$ & $0.0 E+00$ & $0.0 E+00$ \\
\hline $\mathrm{Zr}-95$ & $0.0 E+00$ & $0.0 E+00$ & $0.0 E+00$ & $0.0 E+00$ & $0.0 E+00$ & $0.0 E+00$ \\
\hline $\mathrm{Nb}-95$ & $0.0 E+00$ & $0.0 E+00$ & $0.0 E+00$ & $0.0 E+00$ & $0.0 E+00$ & $0.0 E+00$ \\
\hline$R u-103$ & $0.0 E+00$ & $0.0 E+00$ & $0.0 E+00$ & $0.0 E+00$ & $0.0 E+00$ & $0.0 E+00$ \\
\hline$R u-106$ & $0.0 E+00$ & $0.0 E+00$ & $0.0 E+00$ & $0.0 E+00$ & $0.0 E+00$ & $0.0 E+00$ \\
\hline$S b-125$ & $0.0 E+00$ & $0.0 E+00$ & $0.0 E+00$ & $0.0 E+00$ & $0.0 E+00$ & $0.0 E+00$ \\
\hline $1-129$ * & $0.0 E+00$ & $0.0 E+00$ & $0.0 E+00$ & $0.0 E+00$ & $0.0 E+00$ & $0.0 E+00$ \\
\hline $1-131$ & $0.0 E+00$ & $0.0 E+00$ & $0.0 E+00$ & $0.0 E+00$ & $0.0 E+00$ & $0.0 E+00$ \\
\hline $1-133$ & $0.0 E+00$ & $0.0 E+00$ & $0.0 E+00$ & $0.0 E+00$ & $0.0 E+00$ & $0.0 E+00$ \\
\hline $1-135$ & $0.0 E+00$ & $0.0 E+00$ & $0.0 E+00$ & $0.0 E+00$ & $0.0 E+00$ & $0.0 E+00$ \\
\hline $\mathrm{Xe-131m}$ & & & & & & \\
\hline $\mathrm{Xe}-133$ & & & & 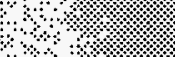 & & $8:$ \\
\hline $\mathrm{Xe}-135$ & & \% & & & \% & ৫. \\
\hline Cs-134 & $0.0 E+00$ & $0.0 E+00$ & $0.0 E+00$ & $0.0 E+00$ & $0.0 E+00$ & $0.0 E+00$ \\
\hline Cs-137 & $0.0 E+00$ & $0.0 E+00$ & $0.0 E+00$ & $0.0 E+00$ & $0.0 E+00$ & $0.0 E+00$ \\
\hline $\mathrm{Ce}-141$ & $0.0 E+00$ & $0.0 E+00$ & $0.0 E+00$ & $0.0 E+00$ & $0.0 E+00$ & $0.0 E+00$ \\
\hline $\mathrm{Ce}-144$ & $0.0 E+00$ & $0.0 E+00$ & $0.0 E+00$ & $0.0 E+00$ & $0.0 E+00$ & $0.0 E+00$ \\
\hline $\mathrm{Pm}-147$ & $0.0 E+00$ & $0.0 E+00$ & $0.0 E+00$ & $0.0 E+00$ & $0.0 \mathrm{E}+00$ & $0.0 E+00$ \\
\hline Eu-154 & $0.0 E+00$ & $0.0 E+00$ & $0.0 E+00$ & $0.0 E+00$ & $0.0 E+00$ & $0.0 E+00$ \\
\hline Eu-155 & $0.0 E+00$ & $0.0 E+00$ & $0.0 \mathrm{E}+00$ & $0.0 \mathrm{E}+00$ & $0.0 E+00$ & $0.0 E+00$ \\
\hline Os-185 & $0.0 E+00$ & $0.0 E+00$ & $0.0 E+00$ & $0.0 E+00$ & $0.0 E+00$ & $0.0 E+00$ \\
\hline$U-234$ & $0.0 E+00$ & $0.0 E+00$ & $0.0 E+00$ & $0.0 E+00$ & $0.0 E+00$ & $0.0 E+00$ \\
\hline U-235 & $0.0 E+00$ & $0.0 E+00$ & $0.0 \mathrm{E}+00$ & $0.0 E+00$ & $0.0 E+00$ & $0.0 E+00$ \\
\hline$U-238$ & $0.0 E+00$ & $0.0 E+00$ & $0.0 E+00$ & $0.0 E+00$ & $0.0 E+00$ & $0.0 E+00$ \\
\hline Np-237 & $0.0 E+00$ & $0.0 E+00$ & $0.0 E+00$ & $0.0 E+00$ & $0.0 E+00$ & $0.0 E+00$ \\
\hline $\mathrm{Pu}-238$ & $0.0 E+00$ & $0.0 E+00$ & $0.0 E+00$ & $0.0 E+00$ & $0.0 E+00$ & $0.0 E+00$ \\
\hline Pu-239 & $0.0 E+00$ & $0.0 E+00$ & $0.0 E+00$ & $0.0 E+00$ & $0.0 E+00$ & $0.0 E+00$ \\
\hline Am-241 & $0.0 E+00$ & $0.0 E+00$ & $0.0 E+00$ & $0.0 E+00$ & $0.0 E+00$ & $0.0 E+00$ \\
\hline Am-243 & $0.0 E+00$ & $0.0 E+00$ & $0.0 E+00$ & $0.0 E+00$ & $0.0 E+00$ & $0.0 E+00$ \\
\hline $\mathrm{Cm}-242$ & $0.0 E+00$ & $0.0 E+00$ & $0.0 E+00$ & $0.0 E+00$ & $0.0 E+00$ & $0.0 E+00$ \\
\hline $\mathrm{Cm}-244$ & $0.0 E+00$ & $0.0 E+00$ & $0.0 E+00$ & $0.0 E+00$ & $0.0 E+00$ & $0.0 E+00$ \\
\hline Cf-252 & $0.0 E+00$ & $0.0 E+00$ & $0.0 E+00$ & $0.0 E+00$ & $0.0 \mathrm{E}+00$ & $0.0 \mathrm{E}+00$ \\
\hline
\end{tabular}

- concentrations determined using element specific model. 


\section{Dose to Maximum Individual Living at the SRS Boundary 50-year CEDE from a 1-Year Intake (mrem)}

\begin{tabular}{|c|c|c|c|c|c|c|}
\hline Nuclide & $\begin{array}{c}\text { Shine Doset } \\
\text { (mrem) }\end{array}$ & $\begin{array}{l}\text { Inhalation } \\
\text { (mrem) }\end{array}$ & $\begin{array}{c}\text { Vegetables } \\
\text { (mrem) }\end{array}$ & $\begin{array}{l}\text { Cow Milk } \\
\text { (mrem) }\end{array}$ & $\begin{array}{c}\text { Meat } \\
\text { (mrem) }\end{array}$ & $\begin{array}{l}\text { TOTAL } \\
\text { (mrem) }\end{array}$ \\
\hline $\mathrm{H}-3$ & & $3.5 \mathrm{E}-02$ & $2.4 E-02$ & $9.7 E-03$ & $4.1 E-03$ & 7.3E-02 \\
\hline$C-14$ & & & $0.0 E+00$ & $0.0 E+00$ & $0.0 E+00$ & $0.0 E+00$ \\
\hline Ar -41 & $0.0 E+00$ & \%:.:- & \% & $44+\%$ & & $0.0 E+00$ \\
\hline $\mathrm{Cr}-51$ & $0.0 E+00$ & $0.0 E+00$ & $0.0 E+00$ & $0.0 E+00$ & $0.0 \mathrm{E}+00$ & $0.0 E+00$ \\
\hline Co-60 & $0.0 E+00$ & $0.0 E+00$ & $0.0 E+00$ & $0.0 E+00$ & $0.0 E+00$ & $0.0 E+00$ \\
\hline $\mathrm{Zn}-65$ & $0.0 E+00$ & $0.0 E+00$ & $0.0 E+00$ & $0.0 E+00$ & $0.0 E+00$ & $0.0 E+00$ \\
\hline Se-75 & $0.0 E+00$ & $0.0 E+00$ & $0.0 E+00$ & $0.0 E+00$ & $0.0 E+00$ & $0.0 E+00$ \\
\hline $\mathrm{Kr}-85$ & $0.0 E+00$ & & & & (1) & $0.0 E+00$ \\
\hline $\mathrm{Kr}-85 \mathrm{~m}$ & $0.0 E+00$ & & & & & $0.0 \mathrm{E}+00$ \\
\hline$K r-87$ & $0.0 E+00$ & & $\%$ & & & $0.0 \mathrm{E}+00$ \\
\hline $\mathrm{Kr}-88$ & $0.0 E+00$ & 14 & $\%$ & & H৷ & $0.0 E+00$ \\
\hline Sr-90 & \% & $0.0 E+00$ & $0.0 E+00$ & $0.0 E+00$ & $0.0 E+00$ & $0.0 E+00$ \\
\hline Zr-95 & $0.0 E+00$ & $0.0 E+00$ & $0.0 E+00$ & $0.0 E+00$ & $0.0 E+00$ & $0.0 E+00$ \\
\hline $\mathrm{Nb}-95$ & $0.0 E+00$ & $0.0 E+00$ & $0.0 E+00$ & $0.0 E+00$ & $0.0 E+00$ & $0.0 E+00$ \\
\hline$R u-103$ & $0.0 E+00$ & $0.0 E+00$ & $0.0 E+00$ & $0.0 E+00$ & $0.0 E+00$ & $0.0 E+00$ \\
\hline$R u-106$ & $0.0 E+00$ & $0.0 E+00$ & $0.0 E+00$ & $0.0 E+00$ & $0.0 E+00$ & $0.0 E+00$ \\
\hline$S b-125$ & $0.0 E+00$ & $0.0 E+00$ & $0.0 E+00$ & $0.0 E+00$ & $0.0 E+00$ & $0.0 E+00$ \\
\hline $1-129$ & $0.0 \mathrm{E}+00$ & $0.0 E+00$ & $0.0 E+00$ & $0.0 E+00$ & $0.0 E+00$ & $0.0 E+00$ \\
\hline$|-13|$ & $0.0 E+00$ & $0.0 E+00$ & $0.0 E+00$ & $0.0 E+00$ & $0.0 E+00$ & $0.0 E+00$ \\
\hline $1-133$ & $0.0 E+00$ & $0.0 E+00$ & $0.0 E+00$ & $0.0 E+00$ & $0.0 E+00$ & $0.0 E+00$ \\
\hline $1-135$ & $0.0 E+00$ & $0.0 E+00$ & $0.0 E+00$ & $0.0 E+00$ & $0.0 E+00$ & $0.0 E+00$ \\
\hline $\mathrm{Xe}-131 \mathrm{~m}$ & $0.0 E+00$ & & & & ४ & $0.0 E+00$ \\
\hline $\mathrm{Xe}-133$ & $0.0 E+00$ & & & & & $0.0 E+00$ \\
\hline$X e-135$ & $0.0 E+00$ & ২) & ४ै। & ঋ:- & భ. & $0.0 E+00$ \\
\hline Cs-134 & $0.0 E+00$ & $0.0 E+00$ & $0.0 E+00$ & $0.0 E+00$ & $0.0 E+00$ & $0.0 E+00$ \\
\hline Cs-137 & $0.0 E+00$ & $0.0 E+00$ & $0.0 E+00$ & $0.0 E+00$ & $0.0 E+00$ & $0.0 E+00$ \\
\hline $\mathrm{Ce}-141$ & $0.0 E+00$ & $0.0 E+00$ & $0.0 E+00$ & $0.0 E+00$ & $0.0 E+00$ & $0.0 \mathrm{E}+00$ \\
\hline Ce-144 & $0.0 E+00$ & $0.0 E+00$ & $0.0 E+00$ & $0.0 E+00$ & $0.0 E+00$ & $0.0 E+00$ \\
\hline$P m-147$ & $0.0 E+00$ & $0.0 E+00$ & $0.0 E+00$ & $0.0 E+00$ & $0.0 E+00$ & $0.0 E+00$ \\
\hline Eu-154 & $0.0 E+00$ & $0.0 E+00$ & $0.0 E+00$ & $0.0 E+00$ & $0.0 E+00$ & $0.0 E+00$ \\
\hline Eu-155 & $0.0 E+00$ & $0.0 E+00$ & $0.0 E+00$ & $0.0 E+00$ & $0.0 E+00$ & $0.0 E+00$ \\
\hline Os-185 & $0.0 E+00$ & $0.0 E+00$ & $0.0 E+00$ & $0.0 E+00$ & $0.0 E+00$ & $0.0 E+00$ \\
\hline$U-234$ & $0.0 E+00$ & $0.0 E+00$ & $0.0 E+00$ & $0.0 E+00$ & $0.0 E+00$ & $0.0 E+00$ \\
\hline$U-235$ & $0.0 E+00$ & $0.0 E+00$ & $0.0 E+00$ & $0.0 E+00$ & $0.0 E+00$ & $0.0 E+00$ \\
\hline U-238 & $0.0 E+00$ & $0.0 E+00$ & $0.0 E+00$ & $0.0 E+00$ & $0.0 E+00$ & $0.0 E+00$ \\
\hline Np-237 & $0.0 E+00$ & $0.0 E+00$ & $0.0 E+00$ & $0.0 E+00$ & $0.0 E+00$ & $0.0 E+00$ \\
\hline Pu-238 & $0.0 E+00$ & $0.0 E+00$ & $0.0 \mathrm{E}+00$ & $0.0 E+00$ & $0.0 E+00$ & $0.0 E+00$ \\
\hline Pu-239 & $0.0 E+00$ & $0.0 E+00$ & $0.0 E+00$ & $0.0 E+00$ & $0.0 E+00$ & $0.0 E+00$ \\
\hline Am-241 & $0.0 E+00$ & $0.0 E+00$ & $0.0 E+00$ & $0.0 E+00$ & $0.0 E+00$ & $0.0 E+00$ \\
\hline$A m-243$ & $0.0 E+00$ & $0.0 E+00$ & $0.0 E+00$ & $0.0 E+00$ & $0.0 E+00$ & $0.0 E+00$ \\
\hline $\mathrm{Cm}-242$ & $0.0 E+00$ & $0.0 E+00$ & $0.0 E+00$ & $0.0 E+00$ & $0.0 E+00$ & $0.0 E+00$ \\
\hline $\mathrm{Cm}-244$ & $0.0 E+00$ & $0.0 E+00$ & $0.0 E+00$ & $0.0 E+00$ & $0.0 E+00$ & $0.0 E+00$ \\
\hline \multirow[t]{2}{*}{ Cf-252 } & $0.0 E+00$ & $0.0 E+00$ & $0.0 E+00$ & $0.0 E+00$ & $0.0 E+00$ & $0.0 E+00$ \\
\hline & $0.0 E+00$ & $3.5 E-02$ & $2.4 \mathrm{E}-02$ & $9.7 \mathrm{E}-03$ & $4.1 E-03$ & 7.3E-02 \\
\hline
\end{tabular}

†Plume-shine doses calculated for noble gases only; others in column are ground-shine doses. 
APPENDIX B

Verification of POPGASP 
Table 1. Meat Production Distribution (kg/yr)

\begin{tabular}{lccccc} 
Sector & 5 to 10 & 10 to 20 & 20 to 30 & 30 to 40 & 40 to 50 \\
\cline { 2 - 6 }$N$ & $0.0 E+00$ & $5.3 E+04$ & $8.8 E+04$ & $2.5 E+05$ & $9.8 E+05$ \\
NNE & $0.0 E+00$ & $5.3 E+04$ & $8.8 E+04$ & $2.0 E+05$ & $4.1 E+05$ \\
NE & $0.0 E+00$ & $7.1 E+04$ & $1.7 E+05$ & $3.5 E+05$ & $4.5 E+05$ \\
ENE & $0.0 E+00$ & $8.3 E+04$ & $2.0 E+05$ & $4.6 E+05$ & $5.7 E+05$ \\
$E$ & $0.0 E+00$ & $8.3 E+04$ & $1.9 E+05$ & $3.4 E+05$ & $5.1 E+05$ \\
ESE & $0.0 E+00$ & $8.3 E+04$ & $1.9 E+05$ & $2.2 E+05$ & $2.5 E+05$ \\
SE & $0.0 E+00$ & $1.2 E+05$ & $2.1 E+05$ & $2.6 E+05$ & $3.0 E+05$ \\
SSE & $0.0 E+00$ & $1.1 E+05$ & $1.9 E+05$ & $2.6 E+05$ & $2.9 E+05$ \\
S & $0.0 E+00$ & $9.4 E+04$ & $1.5 E+05$ & $2.0 E+05$ & $2.7 E+05$ \\
SSW & $0.0 E+00$ & $9.5 E+04$ & $1.8 E+05$ & $2.9 E+05$ & $3.9 E+05$ \\
SW & $0.0 E+00$ & $9.5 E+04$ & $1.7 E+05$ & $2.7 E+05$ & $3.2 E+05$ \\
WSW & $0.0 E+00$ & $9.5 E+04$ & $1.6 E+05$ & $2.3 E+05$ & $4.0 E+05$ \\
$W$ & $0.0 E+00$ & $5.8 E+04$ & $1.0 E+05$ & $2.1 E+05$ & $4.1 E+05$ \\
WNW & $0.0 E+00$ & $4.8 E+04$ & $6.2 E+04$ & $1.3 E+05$ & $2.9 E+05$ \\
NW & $0.0 E+00$ & $5.3 E+04$ & $8.0 E+04$ & $2.8 E+05$ & $2.7 E+05$ \\
NNW & $0.0 E+00$ & $5.3 E+04$ & $8.8 E+04$ & $3.3 E+05$ & $6.2 E+05$
\end{tabular}

Table 2. Milk Production Distribution (L/yr)

\begin{tabular}{lccccc} 
Sector & 5 to 10 & 10 to 20 & 20 to 30 & 30 to 40 & 40 to 50 \\
\cline { 2 - 6 } N & $0.0 E+00$ & $4.2 E+04$ & $6.9 E+04$ & $1.0 E+06$ & $5.3 E+06$ \\
NNE & $0.0 E+00$ & $4.2 E+04$ & $6.9 E+04$ & $2.1 E+05$ & $5.0 E+05$ \\
NE & $0.0 E+00$ & $3.2 E+04$ & $1.0 E+06$ & $2.7 E+06$ & $2.0 E+06$ \\
ENE & $0.0 E+00$ & $2.5 E+04$ & $1.2 E+06$ & $4.4 E+06$ & $5.2 E+06$ \\
E & $0.0 E+00$ & $2.5 E+04$ & $1.4 E+06$ & $3.9 E+06$ & $4.9 E+06$ \\
ESE & $0.0 E+00$ & $2.5 E+04$ & $5.6 E+05$ & $3.0 E+04$ & $4.9 E+05$ \\
SE & $0.0 E+00$ & $2.5 E+03$ & $0.0 E+00$ & $0.0 E+00$ & $0.0 E+00$ \\
SSE & $0.0 E+00$ & $4.8 E+05$ & $8.6 E+05$ & $1.2 E+06$ & $1.2 E+06$ \\
S & $0.0 E+00$ & $1.0 E+06$ & $2.1 E+06$ & $3.0 E+06$ & $3.5 E+06$ \\
SSW & $0.0 E+00$ & $9.9 E+05$ & $3.8 E+06$ & $7.4 E+06$ & $7.6 E+06$ \\
SW & $0.0 E+00$ & $9.9 E+05$ & $2.2 E+06$ & $5.8 E+06$ & $4.8 E+06$ \\
WSW & $0.0 E+00$ & $9.9 E+05$ & $1.7 E+06$ & $2.4 E+06$ & $3.5 E+06$ \\
W & $0.0 E+00$ & $6.7 E+05$ & $1.3 E+06$ & $2.2 E+06$ & $3.6 E+06$ \\
WNW & $0.0 E+00$ & $2.3 E+05$ & $1.1 E+06$ & $1.2 E+06$ & $2.0 E+06$ \\
NW & $0.0 E+00$ & $4.2 E+04$ & $3.8 E+05$ & $1.4 E+06$ & $1.0 E+06$ \\
NNW & $0.0 E+00$ & $4.2 E+04$ & $6.9 E+04$ & $1.7 E+06$ & $3.4 E+06$
\end{tabular}


Table 3. Vegetable Production Distribution (kg/yr)

Distance (miles)

\begin{tabular}{llllll} 
Sector & 5 to 10 & 10 to 20 & 20 to 30 & 30 to 40 & 40 to 50 \\
\cline { 2 - 6 }$N$ & $0.0 E+00$ & $3.6 E+05$ & $6.0 E+05$ & $8.4 E+05$ & $8.7 E+05$ \\
NNE & $0.0 E+00$ & $3.6 E+05$ & $6.0 E+05$ & $5.1 E+05$ & $6.3 E+03$ \\
NE & $0.0 E+00$ & $3.6 E+05$ & $6.9 E+05$ & $1.0 E+06$ & $5.0 E+05$ \\
ENE & $0.0 E+00$ & $3.6 E+05$ & $6.6 E+05$ & $1.2 E+06$ & $1.5 E+06$ \\
E & $0.0 E+00$ & $3.6 E+05$ & $5.9 E+05$ & $8.5 E+05$ & $1.4 E+06$ \\
ESE & $0.0 E+00$ & $3.6 E+05$ & $2.2 E+06$ & $1.9 E+06$ & $1.1 E+06$ \\
SE & $0.0 E+00$ & $2.5 E+06$ & $4.5 E+06$ & $3.0 E+06$ & $1.1 E+06$ \\
SSE & $0.0 E+00$ & $1.7 E+06$ & $2.9 E+06$ & $3.6 E+06$ & $1.1 E+06$ \\
S & $0.0 E+00$ & $7.2 E+04$ & $5.4 E+05$ & $8.4 E+05$ & $9.7 E+05$ \\
SSW & $0.0 E+00$ & $3.5 E+02$ & $1.2 E+05$ & $2.5 E+05$ & $1.1 E+05$ \\
SW & $0.0 E+00$ & $3.5 E+02$ & $7.8 E+02$ & $2.2 E+03$ & $3.1 E+05$ \\
WSW & $0.0 E+00$ & $3.5 E+02$ & $5.8 E+02$ & $9.9 E+02$ & $2.9 E+03$ \\
$W$ & $0.0 E+00$ & $4.5 E+04$ & $2.3 E+04$ & $1.7 E+04$ & $5.2 E+04$ \\
WNW & $0.0 E+00$ & $2.6 E+05$ & $3.8 E+04$ & $4.5 E+05$ & $1.1 E+06$ \\
NW & $0.0 E+00$ & $3.6 E+05$ & $4.3 E+05$ & $8.4 E+05$ & $1.1 E+06$ \\
NNW & $0.0 E+00$ & $3.6 E+05$ & $6.0 E+05$ & $8.4 E+05$ & $1.1 E+06$
\end{tabular}

Table 4. Population Distribution

\begin{tabular}{lccccc} 
& \multicolumn{5}{c}{ Distance (miles) } \\
Sector & 5 to 10 & 10 to 20 & 20 to 30 & 30 to 40 & 40 to 50 \\
\cline { 2 - 6 } NNE & 26 & 5321 & 10020 & 5067 & 12210 \\
NE & 6 & 1320 & 2066 & 4445 & 14370 \\
ENE & 1 & 2945 & 2928 & 5269 & 10200 \\
E & 27 & 3126 & 4483 & 5337 & 40770 \\
ESE & 155 & 6743 & 5305 & 8812 & 4334 \\
IE & 36 & 1556 & 1931 & 2711 & 3253 \\
SSE & 26 & 547 & 6511 & 6685 & 8577 \\
S & 40 & 391 & 769 & 1356 & 2539 \\
SSW & 1 & 558 & 1332 & 7251 & 3335 \\
SW & 2 & 897 & 2008 & 4181 & 2944 \\
WSW & 17 & 944 & 2240 & 2606 & 2660 \\
W & 60 & 1103 & 7112 & 2285 & 5818 \\
WNW & 55 & 3314 & 7941 & 7994 & 6780 \\
NW & 449 & 3342 & 106900 & 50310 & 11550 \\
NNW & 271 & 5899 & 87930 & 26570 & 3025 \\
& 363 & 18030 & 27160 & 6665 & 6079
\end{tabular}


Table 5. Dose Distribution (mrem)

\begin{tabular}{lccccc} 
& \multicolumn{5}{c}{ Distance (miles) } \\
Sector & 5 to 10 & 10 to 20 & 20 to 30 & 30 to 40 & 40 to 50 \\
\cline { 2 - 7 } NNE & $7.5 \mathrm{E}-02$ & $3.3 \mathrm{E}-02$ & $1.7 \mathrm{E}-02$ & $1.1 \mathrm{E}-02$ & $7.7 \mathrm{E}-03$ \\
NE & $6.1 \mathrm{E}-02$ & $2.7 \mathrm{E}-02$ & $1.4 \mathrm{E}-02$ & $9.3 \mathrm{E}-03$ & $6.6 \mathrm{E}-03$ \\
ENE & $6.4 \mathrm{E}-02$ & $2.9 \mathrm{E}-02$ & $1.5 \mathrm{E}-02$ & $1.0 \mathrm{E}-02$ & $7.3 \mathrm{E}-03$ \\
E & $6.4 \mathrm{E}-02$ & $2.6 \mathrm{E}-02$ & $1.3 \mathrm{E}-02$ & $8.8 \mathrm{E}-03$ & $6.4 \mathrm{E}-03$ \\
ESE & $5.2 \mathrm{E}-02$ & $2.1 \mathrm{E}-02$ & $1.1 \mathrm{E}-02$ & $6.9 \mathrm{E}-03$ & $5.1 \mathrm{E}-03$ \\
SE & $4.5 \mathrm{E}-02$ & $1.8 \mathrm{E}-02$ & $9.1 \mathrm{E}-03$ & $6.0 \mathrm{E}-03$ & $4.4 \mathrm{E}-03$ \\
SSE & $3.1 \mathrm{E}-02$ & $1.3 \mathrm{E}-02$ & $6.6 \mathrm{E}-03$ & $4.3 \mathrm{E}-03$ & $3.1 \mathrm{E}-03$ \\
S & $2.5 \mathrm{E}-02$ & $1.1 \mathrm{E}-02$ & $5.7 \mathrm{E}-03$ & $3.8 \mathrm{E}-03$ & $2.8 \mathrm{E}-03$ \\
SSW & $1.4 \mathrm{E}-02$ & $6.2 \mathrm{E}-03$ & $3.4 \mathrm{E}-03$ & $2.4 \mathrm{E}-03$ & $1.8 \mathrm{E}-03$ \\
SW & $4.1 \mathrm{E}-02$ & $1.7 \mathrm{E}-02$ & $9.1 \mathrm{E}-03$ & $6.2 \mathrm{E}-03$ & $4.6 \mathrm{E}-03$ \\
WSW & $6.9 \mathrm{E}-02$ & $2.8 \mathrm{E}-02$ & $1.5 \mathrm{E}-02$ & $9.8 \mathrm{E}-03$ & $7.2 \mathrm{E}-03$ \\
W & $5.4 \mathrm{E}-02$ & $2.2 \mathrm{E}-02$ & $1.2 \mathrm{E}-02$ & $7.9 \mathrm{E}-03$ & $5.8 \mathrm{E}-03$ \\
WNW & $3.9 \mathrm{E}-02$ & $1.6 \mathrm{E}-02$ & $8.8 \mathrm{E}-03$ & $6.0 \mathrm{E}-03$ & $4.3 \mathrm{E}-03$ \\
NW & $4.0 \mathrm{E}-02$ & $1.7 \mathrm{E}-02$ & $9.3 \mathrm{E}-03$ & $6.3 \mathrm{E}-03$ & $4.6 \mathrm{E}-03$ \\
NNW & $5.2 \mathrm{E}-02$ & $2.2 \mathrm{E}-02$ & $1.1 \mathrm{E}-02$ & $7.2 \mathrm{E}-03$ & $5.2 \mathrm{E}-03$ \\
& $6.9 \mathrm{E}-02$ & $3.0 \mathrm{E}-02$ & $1.5 \mathrm{E}-02$ & $9.2 \mathrm{E}-03$ & $6.6 \mathrm{E}-03$
\end{tabular}

Table 6. Population Dose Distribution (person-rem)

\begin{tabular}{lccccc} 
Sector & 5 to 10 & 10 to 20 & 20 to 30 & 30 to 40 & 40 to 50 \\
\cline { 2 - 7 } N & $1.5 \mathrm{E}-03$ & $1.4 \mathrm{E}-01$ & $1.4 \mathrm{E}-01$ & $5.5 \mathrm{E}-02$ & $8.6 \mathrm{E}-02$ \\
NNE & $2.8 \mathrm{E}-04$ & $3.3 \mathrm{E}-02$ & $2.7 \mathrm{E}-02$ & $3.7 \mathrm{E}-02$ & $7.6 \mathrm{E}-02$ \\
NE & $4.9 \mathrm{E}-05$ & $7.4 \mathrm{E}-02$ & $4.4 \mathrm{E}-02$ & $5.3 \mathrm{E}-02$ & $6.7 \mathrm{E}-02$ \\
ENE & $1.3 \mathrm{E}-03$ & $7.0 \mathrm{E}-02$ & $5.7 \mathrm{E}-02$ & $4.7 \mathrm{E}-02$ & $2.3 \mathrm{E}-01$ \\
E & $6.1 \mathrm{E}-03$ & $1.1 \mathrm{E}-01$ & $5.5 \mathrm{E}-02$ & $5.7 \mathrm{E}-02$ & $2.2 \mathrm{E}-02$ \\
ESE & $1.2 \mathrm{E}-03$ & $2.6 \mathrm{E}-02$ & $1.8 \mathrm{E}-02$ & $1.5 \mathrm{E}-02$ & $1.4 \mathrm{E}-02$ \\
SE & $6.1 \mathrm{E}-04$ & $6.6 \mathrm{E}-03$ & $3.9 \mathrm{E}-02$ & $2.6 \mathrm{E}-02$ & $2.3 \mathrm{E}-02$ \\
SSE & $7.6 \mathrm{E}-04$ & $4.3 \mathrm{E}-03$ & $4.4 \mathrm{E}-03$ & $5.2 \mathrm{E}-03$ & $7.1 \mathrm{E}-03$ \\
S & $1.1 \mathrm{E}-05$ & $3.3 \mathrm{E}-03$ & $4.5 \mathrm{E}-03$ & $1.6 \mathrm{E}-02$ & $6.0 \mathrm{E}-03$ \\
SSW & $6.2 \mathrm{E}-05$ & $1.3 \mathrm{E}-02$ & $1.7 \mathrm{E}-02$ & $2.4 \mathrm{E}-02$ & $1.2 \mathrm{E}-02$ \\
SW & $8.9 \mathrm{E}-04$ & $2.3 \mathrm{E}-02$ & $2.9 \mathrm{E}-02$ & $2.2 \mathrm{E}-02$ & $1.8 \mathrm{E}-02$ \\
WSW & $2.5 \mathrm{E}-03$ & $2.1 \mathrm{E}-02$ & $7.3 \mathrm{E}-02$ & $1.6 \mathrm{E}-02$ & $2.9 \mathrm{E}-02$ \\
W & $1.6 \mathrm{E}-03$ & $4.6 \mathrm{E}-02$ & $5.9 \mathrm{E}-02$ & $4.1 \mathrm{E}-02$ & $2.5 \mathrm{E}-02$ \\
WNW & $1.4 \mathrm{E}-02$ & $5.0 \mathrm{E}-02$ & $7.6 \mathrm{E}-01$ & $2.5 \mathrm{E}-01$ & $4.9 \mathrm{E}-02$ \\
NW & $1.1 \mathrm{E}-02$ & $1.1 \mathrm{E}-01$ & $7.4 \mathrm{E}-01$ & $1.6 \mathrm{E}-01$ & $1.6 \mathrm{E}-02$ \\
NNW & $1.9 \mathrm{E}-02$ & $4.2 \mathrm{E}-01$ & $3.2 \mathrm{E}-01$ & $5.9 \mathrm{E}-02$ & $4.0 \mathrm{E}-02$
\end{tabular}

Total Population Dose: $\quad 5.2 E+00$ person-rem 